\title{
DYNAMICS OF REGIONAL DISTRIBUTION AND ECOLOGY INVESTIGATION OF RARE MAMMALS OF TAIGA EURASIA (CASE STUDY OF FLYING SQUIRREL PTEROMYS VOLANS, RODENTIA, PTEROMYIDAE)
}

\author{
Juri P. Kurhinen ${ }^{1,2}$, Vladimir N. Bolshakov ${ }^{3}$, Svetlana N. Bondarchuk ${ }^{4}$, \\ Elena V. Vargot ${ }^{5,6,7}$, Sergey N. Gashev ${ }^{8}$, Elena A. Gorbunova ${ }^{9}$, Evgeniy S. Zadiraka ${ }^{10}$, \\ Ernest V. Ivanter ${ }^{11}$, Sergey K. Kochanov ${ }^{12}$, Elena V. Kulebyakina ${ }^{13}$, Viktor N. Mamontov ${ }^{13}$, \\ Artur V. Meydus ${ }^{14}$, Evgenia A. Muravskaya ${ }^{15}$, Dmitriy S. Nizovtsev, \\ Tatyana E. Pavlyushchik ${ }^{16}$, Valdis Pilats ${ }^{17}$, Andrey V. Sivkov ${ }^{18}$, Natalja S. Sikkilya ${ }^{19}$, \\ Leonid V. Simakin ${ }^{20}$, Evgeniy N. Smirnov ${ }^{4}$, Uudo Timm², Ilpo K. Hanski ${ }^{1,22}$

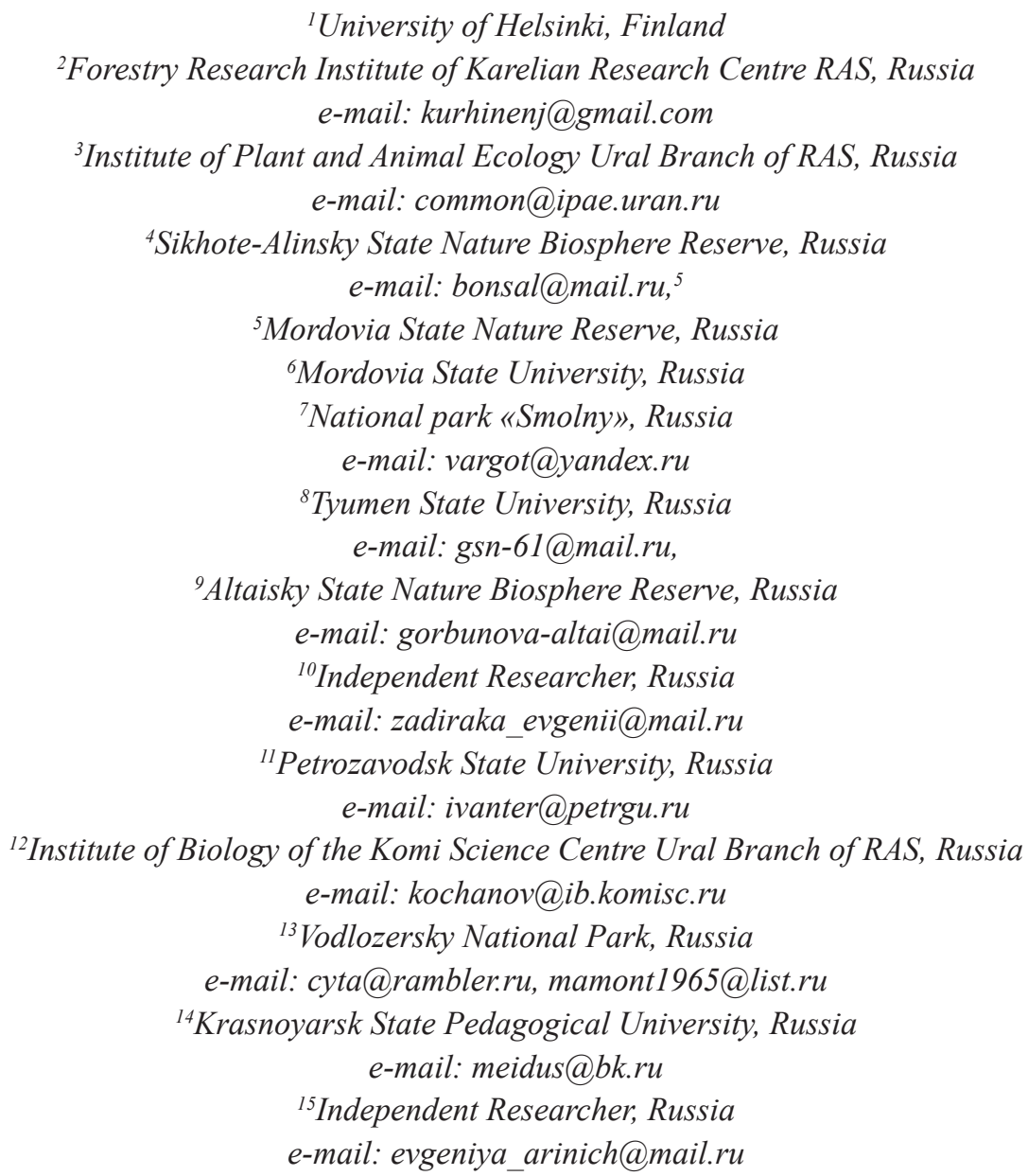 \\ ${ }^{16}$ Scientific-Practical Center of Biological Resources, National Academy of Sciences of Belarus, Republic of Belarus \\ e-mail: tatiana.pavlushchick@gmail.com \\ ${ }^{17}$ Nature Conservation Agency of Latvia, Latvia \\ e-mail:valdis.pilats@daba.gov.lv \\ ${ }^{18}$ Pinega State Nature Reserve, Russia \\ e-mail:pinzapno@mail.ru \\ ${ }^{19}$ Kostomukshsky State Nature Reserce, Russia \\ e-mail:natik.zam@gmail.com \\ ${ }^{20}$ Pechora-Ilych State Nature Biosphere Reserve, Russia \\ e-mail:pechilzap@mail.ru \\ ${ }^{21}$ Estonian Environment Agency, Estonia \\ e-mail: Uudo.Timm@envir.ee \\ ${ }^{22}$ Finnish Museum of Natural History, Finland \\ e-mail: ilpo.hanski@helsinki.fi
}

Received: 30.09.2016 
This study of the spatial distribution and ecology of the flying squirrel during the turn of the $20^{\text {th }}$ century provides a description of new methods and techniques for detecting and accounting flying squirrels in the forest zone of Eurasia. The flying squirrel population area covers the territory of 61 regions of Russia, including Kamchatsky Krai and Chukotka Autonomous District. The number of flying squirrels in Karelia especially to the east - in the Arkhangelsk region and Western Siberia - significantly exceeds that of Finland, but considerable spatial variability in the number is obvious through all the regions: there are areas where this animal is quite abundant, or inhabits all the territory rather evenly, and there are areas where it is completely absent in vast territories even with seemingly favourable conditions. The flying squirrel is quite difficult to study and the reasons of its absence in obviously favourable areas are still to be explained. Some reasons are: the specificity of favourable landscape, forest coverage pattern, trophic relationships with predators and genetic aspect. A number of hypotheses are supposed to be tested in the nearest future.

Key words: accounting, flying squirrel, forest zone, home range, spatial distribution.

\section{Introduction}

The Siberian flying squirrel (Pteromys volans L.) is a specialized dendrobiont, adapted to life in the top layers of the forest (Fig. 1), the only member of the family (according to other sources - subfamily) of Old World flying squirrels in the territory of Russia. It is included in the Red Data Book of East Fennoscandia (Hokkanen \& Fokin, 1998), the Baltic region (Ingelög et al., 1993), Finland (Rassi et al., 2001), Estonia (Red Data Book of Estonia, 2008), the Republic of Belarus (Grichik, 2006). On the IUCN Red List it has currently the status of LC (Least Concern - Lowest Risk, 2008), in the previous version - LR/NT (Lower Risk / Near Threatened, 1996). Pteromys volans was originally described as Sciurus volans (Linnaeus, 1758) based on a specimen from Sweden. In the first half of the XX century Ognev (1940) distinguished 9 subspecies of $P$. volans, and referred flying squirrels, common in the north of European Russia and in the Urals, to the subspecies $P$. $v$ volans. Despite the great interest of researchers, until recently the ecology of flying squirrels in the wild has been studied quite poorly. This work is to partly fill this gap, as we have accumulated additional material since the release of our latest publication (Ivanter et al., 2009a; Kurhinen et al., 2010). We believe that the lack of data on this species distribution is associated with the complexities of its detection in the wild. The Siberian flying squirrel is a small and extremely agile animal, mainly crepuscular or nocturnal. Meanwhile, techniques suggested here can quite accurately determine the abundance of the species in the investigated territory.

\section{Material and Methods}

To study the flying squirrel's spatial distribution we used the discount areas method by Hanski (1998) and Hanski et al., (2000), based on telemetry research of female flying squirrel's home ranges size and location. It was successfully tested in Finland and on the Karelian Isthmus in the early $21^{\text {st }}$ century (Hanski et al., 2004, 2006). Using telemetry Hanski (1998) collected reliable data on the territo- rial structure of the population which, subsequently, created the ground for modifications of the proposed method, making it more appropriate and accurate. Later studies on population ecology of the species spread over the entire territory of East Fennoscandia (and even western Siberia) involved other authors of the present study. In 2004-2010 this method was actively used first in Karelia, then in the Arkhangelsk region and beyond - to Western Siberia. In addition to our own data we used results by other researchers in Finland, obtained within a joint project (Hanski et al., 2004, 2006, 2008). In recent years, Protected Areas' employees of scientific departments in Russia (Pinega State Nature Reserve, Vodlozersky National Park, Altai and the Sikhote-Alin Reserve, PechoraIlych Reserve, Kostomukshsky Reserve) and a number of Scientific Research Institutes of Russian Academy of Science have paid particular attention to this problem.

According to researchers from Finland (Hanski, 1998; Hanski et al., 2000) the home range of adult female flying squirrels concerns approximately 0.083 $\mathrm{km}^{2}$. The boundaries almost never overlap and females vigorously defend their territory against other females. Young females leave mother's nest earlier than males and, as a rule, settle on over a distance of $400 \mathrm{~m}$ from the center of their mother's home range (in some cases up to $8 \mathrm{~km}$ or more). Young males disperse less and later, their territories overlap up to $38 \%$. Their home ranges of about $0.08-0.09 \mathrm{~km}^{2}$ concentrate around female's area, slightly overlapping with it. Male home ranges are undefined in size and location, have blurred borders, and often overlap with areas of neighbours. The described situation is well illustrated by the real picture of several neighbouring animals' distribution, observed in the southeast of Finland (Fig. 2).

Despite the apparent complexity of the proposed method it does not require much time and effort. Only two people during a week of work were enough to explore a square area of $100 \mathrm{~km}^{2}$. In Karelia the full scope of the three-year accounting in the area of $83.43 \mathrm{~km}^{2}$ required a team of 11 spe- 
cially trained fieldworking students to inspect 927 discount areas. Due to the fact that the home ranges of adult female flying squirrels are separate and quite constant in size we were able to develop the cartographic basis for accounting areas system optimization. This accounting method was previously described in more detail (Hanski et al., 2006; Ivanter et al., 2009b; Kurhinen et al., 2010).

\section{Results and Discussion}

RANGE AND LEGAL STATUS OF FLYING SQUIRRELS IN RUSSIA. Being quite extensive in the past, the flying squirrel range has significantly changed over the past 100-200 years, mainly on boundaries. In the Russian Federation the flying squirrel range extends to most of the area, covering forest zone and taiga. The flying squirrel range includes the territory of 61 regions of Russia, including the Kamchatsky Krai and Chukotka Autonomous District, where the species is found in very limited territories, as well as the cities of federal status: Moscow and St. Petersburg. In 2014 we confirmed flying squirrels inhabiting the territory of New Moscow (due to changes in the city boundaries the animal world objects shifted from the territory of Moscow region, to the city and changed protected status according to the Red Book of Moscow); within the boundaries of St. Petersburg the flying squirrel occurs in the reserve "Lake Shchyuchye» (Volobuev, pers. comm.). However, data for some regions are still to be confirmed, especially at the outskirts of the range. Material on the flying squirrel in the Urals for the period 1956-2014 include data of direct observations, occasional prey by hunters, incidental catch and specimens stored in the museums of the Institute of Plant and Animal Ecology, Ural Branch of Russian Academy of Sciences and the Zoology Department of the Ural State University. In total there were registered more than 80 range spots of this species in the Middle and Northern Urals. The largest number (more than 60) was recorded in the Sverdlovsk region, sporadically they occur on the territory of Permsky Krai, Komi Republic and Chelyabinsk region. The flying squirrel obviously prefers the old dark coniferous forests, especially those directly along the Ural Mountains.

Information on flying squirrels in Central Siberia comprises of fragmentary data in species studies (Kokhanowski, 1962). We have found that the flying squirrel is a regular species in the forests of the lower and middle mountains belt in Eastern Sayan. Animals willingly occupied nesting boxes for owls. In every case we registered breeding, collected data on phenology and other biology aspects.

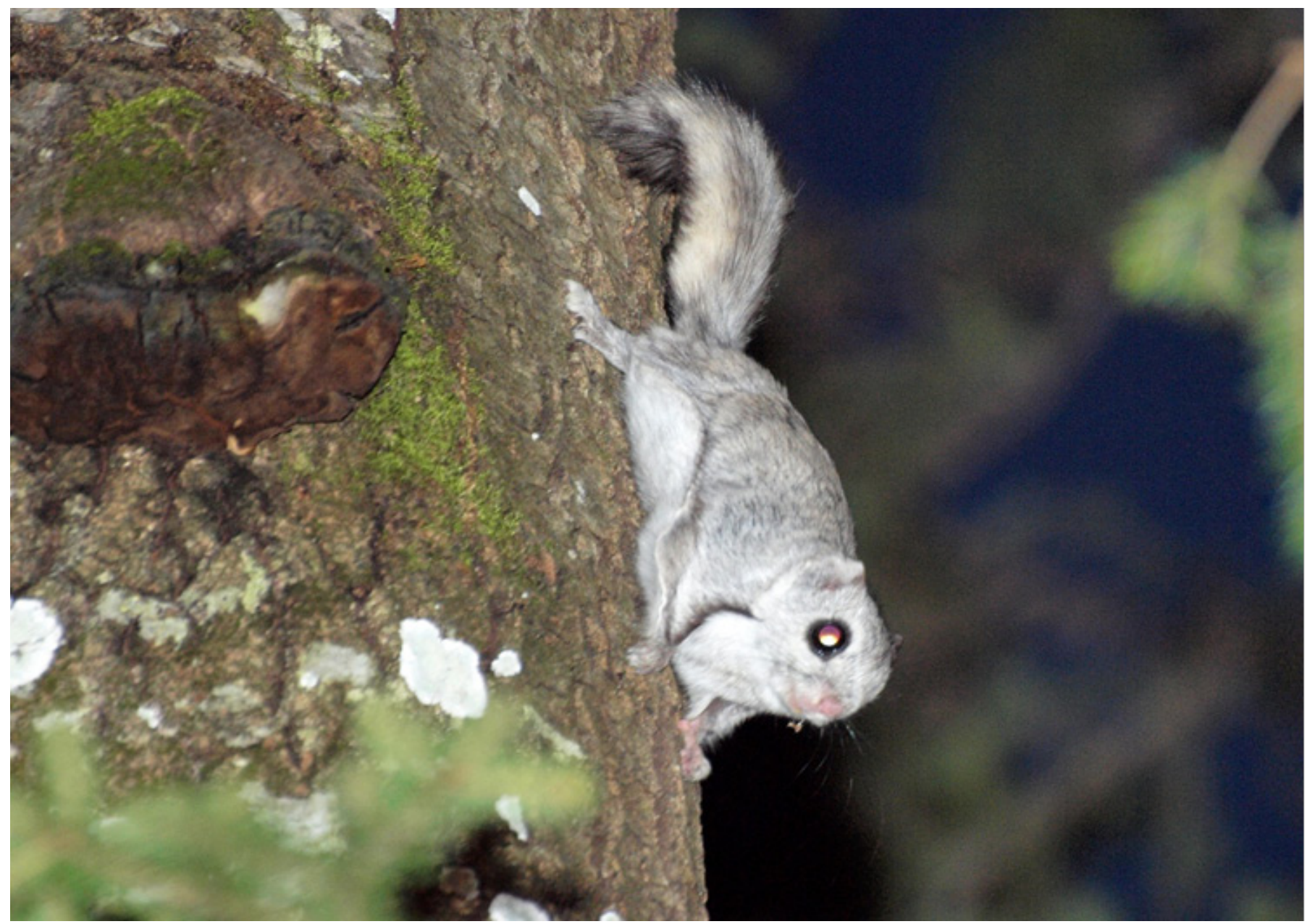

Fig. 1. Flying squirrel, Pteromys volans, in neighbourhood of Petrozavodsk (photo: E. Zadiraka). 


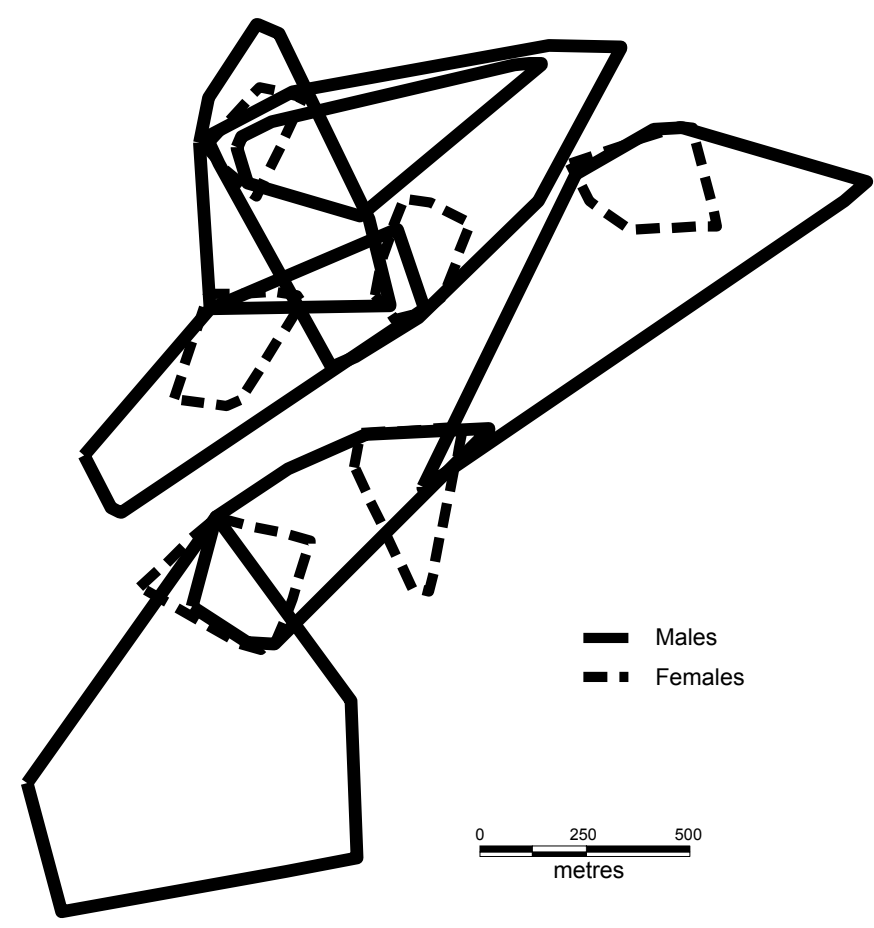

Fig. 2. Home ranges of males (solid lines) and females of flying squirrel (dashed lines) based on telemetry studies in the southeast of Finland (according to Hanski, 1998, as amended).

Owl trophic relations investigation showed that the flying squirrel is an occasional prey of this predator in the Cannes depression, in the south-western part of the South Minusinsk Depression (middle reach of the river Tashtyp), and sporadically along the eastern foothill of Kuznetsky Alatau. In Krasnoyarsk, this species was found in owl pellets in two perennial nests, although its share in an owl prey never exceeded $1 \%$. This data is sufficient to say that the flying squirrel range covers a large part of southern Siberia - mainly its forest and mountain-forest parts.

THE LEGAL STATUS. Presently, in the Russian Federation the flying squirrel is listed in the Red Data Books and on protected species lists of 27 federal subjects with statuses between 4 (rare or insufficiently studied species) to 0 (possibly extinct). This species is included in the new edition of the Red Books of Vologda region (2010), Kurgan region (Polyakov \& Modorov, 2012) and Pskov region (Istomin, 2004); in the Red Book of Moscow region its status was changed from 3 (rare) (Zubakin, 1998) to 1 (endangered species) (Emeljanova, 2008). Currently the flying squirrel is listed in the Red Data Books of the subjects in the north-western, western and south-western borders of its range, although in most of its range it is on the list of game species, being thus not only unprotected, but even vulnerable. The flying squirrel is relatively rare, though still unprotected, in some regions along the southern border of the range (Khakassia, Southern Altai) (Devyatkin et al., 2000; Prokopov, 2008). Apparently, the number of flying squirrels does not cause concern only in the central part of its range. According to Tyumen region data, the species population can be considered quite stable: it is proposed to exclude the flying squirrel from the next edition of the Red Data Book (Nizovtsev \& Gashev, 2013; Gashev, pers. comm.). In the western and north-western parts of the Eurasian forest zone such significant changes in the range of the flying squirrel have occurred that a separate study will be devoted to this phenomenon.

ACCOUNTING. For a more objective analysis of the obtained material we have compared statistical analysis of the species accounting data and Forest Fund material of different regions to investigate the correlation between the territorial distribution of the flying squirrel and landscape dynamics and structure. For easier use of statistical programs (the SYSTAT) the investigated area was divided into squares $50 \times 50 \mathrm{~km}$ (according to UTM co-ordinate system, more than 100 squares) then received data on the flying squirrels number was supplemented by the taiga landscapes structure information.

Table. Flying squirrel abundance in the northwest of the forest zone of Eurasia

\begin{tabular}{|l|c|c|c|}
\hline \multicolumn{1}{|c|}{ Region } & $\begin{array}{c}\text { Number of investigated } \\
\text { accounting areas }\left(0.09 \mathrm{~km}^{2}\right)\end{array}$ & $\begin{array}{c}\text { Number of accounting areas, } \\
\text { inhabited by flying squirrel }\end{array}$ & $\begin{array}{c}\text { \% of inhabited } \\
\text { areas }\end{array}$ \\
\hline Finland & 10032 & 1031 & 10.3 \\
\hline Karelian Isthmus & 707 & 88 & 12.4 \\
\hline Russian Karelia & 937 & 119 & 12.7 \\
\hline Arkhangelsk region & 110 & 38 & 34.5 \\
\hline $\begin{array}{l}\text { Boundary regions of the Vologda and Leningrad } \\
\text { regions, Natural Park «Vepsian forest» }\end{array}$ & 23 & 15 & 65.2 \\
\hline Tyumen region & 110 & 52 & 47.3 \\
\hline Total & 11919 & 1343 & 11.3 \\
\hline
\end{tabular}


In general, the number of flying squirrels in Karelia, and especially to the east - in the Arkhangelsk region and Western Siberia - significantly exceeds that of Finland, but considerable spatial variability in number is obvious through all the regions: where this animals is quite abundant, or inhabits all the territory rather evenly, and there are areas where it is completely absent in vast territories even with the seemingly favourable conditions. In Fennoscandia to definitely unfavourable habitats can be referred rocky landscapes and heavily waterlogged areas, dominated by pine forests at the White Sea coastland.

FLYING SQUIRREL TELEMETRY. In the winter 2012-2013 for the first time on the territory of Russia flying squirrel telemetry studies took place in the south-west of the Arkhangelsk region (Mamontov et al., 2015). There were identified the size of the winter home range $\left(0.0366 \mathrm{~km}^{2}\right)$, the average distance of male flying squirrels from the covert over night (49.4 $\pm 35.3 \mathrm{~m}, \mathrm{n}=78$ ), the maximum distance during the rutting season $-1282 \mathrm{~m}$. The structure of habitats on the used section, on the accessible territory (in a 100 $\mathrm{m}$ radius around the coverts), on the border territories (100-150 $\mathrm{m}$ from the coverts) and in the investigated area were studied as well. It was discovered that the flying squirrel is very selective in choosing a habitat. The used section and accessible territory were dominated by mixed stands with predominance of spruce at the age of 65 and 100 years.

USE OF SPECIAL TECHNICAL DEVICES (PHOTO-TRAPS, VOICE RECORDER). A number of reserves have used camera traps for flying squirrel monitoring. For example, the Pechora-Ilych Nature Reserve (Leonid Simakin) collected unique data on the behaviour of the flying squirrel and sable. We should note that in the plains and foothills in PechoraIlych Nature Reserve a significant part of the material was obtained while live trapping other animals (these studies were carried out by Sokolskiy, Kudryavtseva, Teplova (Bobretsov et al., 2004). Very curious material on the dynamics of the daily activities of the flying squirrel was collected by E. Zadiraka.

\section{Conclusions}

The factors of the uneven spatial distribution of the flying squirrel in the forest area are not fully understood. It is only obvious that this species avoids large areas of wetlands, rocky pine forests and open marshes, i.e. habitats, usually occupying significant part of the region. It is possible that causes of its range limits to the west (with a noticeable reduction in the range) are completely different compared to those in the north (the northern boundary of the range). In both cases, it has to be a complex of factors (for example, in the west - the extreme fragmentation of habitats into-a mosaic landscapes, and in the north - the spread of pine forests and open marshes). Statistical analysis of the surveys shows an obvious correlation between the spatial distribution of the flying squirrels and the forest cover degree: where the forest area is less than $85 \%$, there is a clear correlation between this indicator and the number of flying squirrels (correlation coefficient of $+0.73, p$ $<0.01$ ). In other words, the decline of forest cover in different regions of the taiga zone inevitably leads to a reduction in the population of flying squirrels, reaching a minimum in areas where the forest coverage is $31 \%$ or lower.

However, this is only a partial explanation for such an uneven distribution of the flying squirrels. The flying squirrel is still quite difficult to study and reasons for the absence of this species in certain very favourable habitats still needs to be explained. Some reasons are: the specificity of favourable landscape, forest coverage pattern, trophic relationships with predators and genetic aspect. A number of hypotheses are supposed to be tested in the nearest future.

\section{Acknowledgements}

This work was conducted in the development process of the Russian-Finnish international project "Linking environmental change to biodiversity change: long-term and large-scale data on European boreal forest biodiversity" (2011-2015), and in framework of the state task of the Forest Research Institute of Karelian Research Centre RAS (topic number 0220-2015-00014).

\section{References}

Bobretsov A.B., Neyfeld N.D., Sokolskiy S.M., Teplov V.V., Teplova V.P., Kupriyanov A.G. 2004. Mammals of the Pechora-Ilychsky Reserve. Syktyvkar: Komi Book Publisher. 210 p. [In Russian]

Bolotov N.L., Ivanter E.V., Krivokhatskiy V.A. 2010. Red Data Book of the Vologda region. Animals. Vol. 3. Vologda: Poligraf-Kniga. 216 p. [In Russian]

Devyatkin G.V., Kustov Yu.I., Lipatkina O.O., Okaemov S.A., Prokofjev S.N., Rogacheva E.V., Sannikova I.V., Syroechkovskiy E.E., Shtilmark F.R. 2000. Khakassky Reserve. In: Reserves of Russia. Reserves of Siberia. II. Moscow: Logata. P. 129-143. [In Russian]

Emeljanova L.G. 2008. Siberian flying squirrel. In: T.I. Varlygina, V.A. Zubakin, N.A. Sobolev (eds.): Red Data Book of Moscow region. Moscow: KMK Scientific Press Ltd. 827 p. [In Russian]

Grichik V.V. 2006. Siberian flying squirrel. In: Red Data Book of the Republic of Belarus. Animals. Rare and endangered species of wild animals. Minsk: Publisher «Belarusian Encyclopedia». 320 p. [In Russian]

Hanski I.K. 1998. Home ranges and habitat use in the declining flying squirrel Pteromys volans in managed forests. Wildlife Biology 4 (1): 33-46.

Hanski I.K., Kurhinen Ju.P., Danilov P.I., Belkin V.V. 2004. Study of Pteromys volans abundance in Fennoscandia: Finland's experience and prospects in North-Western Russia. In: Anthropogenic Transformation of Taiga Ecosystems in Europe: Environmental, Resource and Economic Implications. Petrozavodsk. P. 217-219. [In Russian] 
Hanski I.K., Kurhinen Ju.P., Danilov P.I., Verevkin M.V., Ivanter E.V., Belkin V.V., Kulebyakina E.V. 2006. Topographic distribution and density of Pteromys volans in the North-West of Russia. In: Population dynamics of hunting animals in Northern Europe. Petrozavodsk. P. 121-122. [In Russian]

Hanski I.K., Kurhinen Ju.P., Ivanter E.V., Kulebyakina E.V., Zadiraka E.S. 2008. Siberian flying squirrel (Pteromys volans L.) in taiga ecosystems of Fennoscandia: experience of international studies. In: Northern territories of Russia: problems and development prospects. Arkhangelsk: Institute of Ecological Problems of the North, Ural Branch of RAS. P. 1445-1448. [In Russian]

Hanski I.K., Stevens P., Ihalempia P., Selonen V. 2000. Home range size, movements, and nest site use in the Siberian flying squirrel, Pteromys volans. Journal of Mammalogy 81 (3): 798-809.

Hokkanen H., Fokin I. 1998. Pteromys volans. In: H. Kotiranta., P. Uotila, S. Sulkava, S.-L. Peltonen (eds.): Red Data Book of East Fennoscandia. Helsinki: Ministry of the Environment, Finnish Environment Institute \& Botanical Museum, Finnish Museum of Natural History. P. 203-205.

Ingelög T., Andersson R., Tjernberg M. (eds.). 1993. Red Data Book of the Baltic Region. Uppsala: Swedish Threatened Species Unit. 95 p.

Istomin A.V. 2004. Siberian flying squirrel. In: A.V. Istomin, V.Yu. Musatov, T.E. Mozhzhina (eds.): Red Data Book of Pskov region. Pskov. P. 479. [In Russian]

Ivanter E.V., Kurhinen Ju.P., Hanski I.K., Kulebyakina E.V. 2009a. Spatial distribution and abundance of flying squirrels in the Fennoscandia. In: Transactions of Karelian Research Centre of Russian Academy of Sciences. Biogeography series 8 (1): 69-74. [In Russian]

Ivanter E.V., Kurhinen Ju.P., Kulebyakina E.V., Hanski I.K., Zadiraka E.S. 2009b. A new technique for estimating the abundance of the flying squirrel (Pteromys volans, Rodentia, Pteromyidae), its approbation and preliminary results. Russian Journal of Zoology 88 (11): 1396-1401. [In Russian]

Kokhanowski N.A. 1962 Mammals of Khakassia. Abakan: Khakknigoizdat. 173 p. [In Russian]

Kulebyakina E.V. 2006. Topographic distribution and density of flying squirrels Pteromys volans in the northwest of Russia. In: Population dynamics of hunting animals in Northern Europe. Petrozavodsk. P. 121-122. [In Russian]
Kurhinen Ju.P., Hanski I.K., Kulebyakina E.V., Zadiraka E.S. 2010. Mapping distribution and relative abundance of the Flying Squirrel Pteromys volans in North-European boreal forests. In: Wildlife census methods: reliability and application. Kaunas. P. 31-34. [In Lithuanian and English]

Mamontov V.N., Kurhinen Ju.P., Hanski I.K. 2015. Radio telemetry of the Siberian flying squirrel (Pteromys volans L.) in the southwest of the Arkhangelsk region: the first results. Transactions of Karelian Research Centre of Russian Academy of Science. Biogeography 4: 94-102. [In Russian]

Nizovtsev D.S., Gashev S.N. 2013. Biology of flying squirrels in the south of the Tyumen region. Vestnik of Tyumen State University 6: 79-86. [In Russian]

Ognev S.I. 1940. Mammals of USSR and adjacent countries. Vol. 4. Moscow-Leningrad: Publishing House of AS USSR. 616 p. [In Russian]

Polyakov V.E., Modorov M.V. 2012. Pteromys volans (Linnaeus, 1758). In: Red Data Book of the Kurgan region. Kurgan: Publishing House of the Kurgan State University. 448 p. [In Russian]

Prokopov K.P. 2008. Biotopic distribution and abundance of mammal fauna in Southern Altai. In: Biodiversity, ecological problems of mountainous Altai and adjacent regions: present, past, future. Part 1. Gorno-Altaisk. Available at: http://e-lib.gasu.ru/konf/ biodiversity/2008/1/index.html

Rassi P., Alanen A., Kanerva T., Mannerkoski I. (eds.). 2001. The 2000 Red List of Finnish Species. Helsinki: Ympäristöministeriö \& Suomen ympäristökeskus. 685 p. [In Finnish]

Red Data Book of Estonia. Tartu: Estonian Academy of Sciences, Commission for Nature Conservation, 2008. 453 p.

Red Data Book of Vologda region. Vol. 3: Animals. Vologda: Rus', 2004. 360 p. [In Russian]

Zadiraka E.S. 2011. Territorial distribution and biology of the Siberian flying squirrel, Pteromys volans L.) in taiga ecosystems of European Russia and Ural. PhD thesis abstract. Petrozavodsk. 17 p. [In Russian]

Zubakin V.A. 1998. Siberian flying squirrel. In: V.A. Zubakin, V.N. Tikhomirov (eds.): Red Data Book of the Moscow region. Moscow: «Argus»; «Russkiy universitet». P. 22-23. [In Russian]

\section{ИССЛЕДОВАНИЕ ДИНАМИКИ ТЕРРИТОРИАЛЬНОГО РАСПРОСТРАНЕНИЯ И ЭКОЛОГИИ РЕДКИХ МЛЕКОПИТАЮЩИХ ТАЕЖНОЙ ЕВРАЗИИ (НА ПРИМЕРЕ ЛЕТЯГИ РТЕRОMYS VOLANS, RODENTIA, PTEROMYIDAE)}

Ю. П. Курхинен ${ }^{1,2}$, В. Н. Большаков ${ }^{3}$, С. Н. Бондарчук ${ }^{4}$, Е. В. Варгот ${ }^{5,6,7}$, С. Н. Гашев ${ }^{8}$, Е. А. Горбунова ${ }^{9}$, Е. С. Задирака ${ }^{10}$, Э. В. Ивантер ${ }^{11}$, С. К. Кочанов ${ }^{12}$, Е. В. Кулебякина ${ }^{13}$, В. Н. Мамонтов ${ }^{13}$, А. В. Мейдус ${ }^{14}$, Е. А. Муравская ${ }^{15}$, Д. С. Низовцев ${ }^{8}$, Т. Е. Павлюшчик ${ }^{16}$, В. Пилатс ${ }^{17}$, А. В. Сивков ${ }^{18}$, Н. С. Сиккиля ${ }^{19}$, Л. В. Симакин ${ }^{20}$, Е. Н. Смирнов ${ }^{4}$, У. Тимм ${ }^{21}$, И. К. Хански ${ }^{1,22}$

${ }^{l}$ Университет Хельсинки, Финляндия

${ }^{2}$ Институт леса Карельского научного Центра РАН, Россия e-mail:kurhinenj@gmail.com

${ }^{3}$ Институт экологии растений и животных УрО РАН, Россия e-mail:common@ipae.uran.ru

${ }^{4}$ Сихотэ-Алинский государственный природный биосферный заповедник имени К.Г. Абрамова, Россия e-mail:bonsal@mail.ru 
${ }^{5}$ Мордовский государственный природный заповедник имени П. Г. Смидовича, Россия

${ }^{6}$ Мордовский государственныій университет имени Н. П. Огарева, Россия

${ }^{7}$ Национальный парк "Смольный», Россия e-mail:vargot@yandex.ru

${ }^{8}$ Тюменский государственный университет, Россия e-mail:gsn-61@mail.ru,

${ }^{9}$ Алтайский государственныий природный биосферный заповедник, Россия e-mail: gorbunova-altai@mail.ru

${ }^{10}$ Индивидуальныий исследователь, г. Петрозаводск, Россия e-mail: zadiraka_evgenii@mail.ru

${ }^{11}$ Петрозаводский государственный университет, Россия e-mail: ivanter@petrgu.ru

${ }^{12}$ Институт биологии Коми научного иентра Уральского отделения РАН, Россия e-mail:kochanov@ib.komisc.ru

${ }^{13}$ Водлозерский национальный парк, Россия

e-mail:cyta@rambler.ru,mamont1965@list.ru

${ }^{14}$ Красноярский государственный педагогический университет, Россия e-mail:meidus@bk.ru

${ }^{15}$ Индивидуальный исследователь, г. Петрозаводск, Россия e-mail: evgeniya_arinich@mail.ru

${ }^{16}$ Научно-практический центр биологических ресурсов Национальной академии наук Беларуси, Республика Беларусь e-mail: tatiana.pavlushchick@gmail.com

${ }^{17}$ Агентство по охране природы Латвии, Латвия e-mail:valdis.pilats@daba.gov.lv

${ }^{18}$ Пинежский государственный природный заповедник, Россия e-mail:pinzapno@mail.ru

${ }^{19}$ Костомукшский государственный природный заповедник, Россия e-mail:natik.zam@gmail.com

${ }^{20}$ Печоро-Ильчский государственный природный биосферный заповедник, Россия e-mail:pechilzap@mail.ru

${ }^{21}$ Агентство окружающей среды Эстонии, Эстония e-mail:Uudo.Timm@envir.ee

${ }^{22}$ Финский музей естественной истории, Финляндия e-mail:ilpo.hanski@helsinki.fi

В работе рассматриваются исследования территориального распространения и экологии летяги на территории лесной зоны Евразии, в период рубежа 20-21 вв. Дается описание новых методов и способов обнаружения и учета численности летяги в лесной зоне Евразии. Область обитания летяги включает территории 61 субъекта РФ, в их числе - Камчатский край и Чукотская автономная область. Численность летяги в Карелии и тем более к востоку - в Архангельской области и Западной Сибири существенно выше, чем в Финляндии, но в во всех регионах отмечена значительная пространственная вариабельность численности летяги: есть районы, где численность зверьков довольно велика, и они достаточно равномерно заселяют всю территорию, а есть места, где они полностью отсутствуют на больших площадях даже при наличии внешне благоприятных условий. Летяга остается довольно сложным для изучения видом причем причины отсутствия вида в некоторых весьма благоприятных местообитаниях еще ждут своего объяснения. Среди причин - ландшафтная специфика местообитаний, характер растительности и трофические взаимосвязи с хищниками, генетический аспект. Ряд гипотез предполагается апробировать в ближайшее время.

Ключевые слова: летяга, учет численности, ареал, лесная зона, территориальное распространение. 